\title{
PSMC2 wt Allele
}

National Cancer Institute

\section{Source}

National Cancer Institute. PSMC2 wt Allele. NCI Thesaurus. Code C106090.

Human PSMC2 wild-type allele is located within 7q22.1-q22.3 and is approximately $25 \mathrm{~kb}$ in length. This allele, which encodes 265 protease regulatory subunit 7 protein, plays a role in both ATP hydrolysis and the modulation of proteasomal activity. 